\title{
The relevance of uncertainty in future crop production for mitigation strategy planning
}

K. Frieler ${ }^{1}$, A. Levermann ${ }^{1}$, J. Elliott ${ }^{2,3}$, J. Heinke ${ }^{1}$, A. Arneth ${ }^{4}$, M. F. P. Bierkens ${ }^{5}$, P. Ciais ${ }^{6}$, D. B. Clark ${ }^{7}$, D. Deryng ${ }^{8}$, P. Döll ${ }^{9}$, P. Falloon ${ }^{10}$, B. Fekete ${ }^{11}$, C. Folberth ${ }^{12}$, A. D. Friend ${ }^{13}$, C. Gellhorn ${ }^{1}$, S. N. Gosling ${ }^{14}$, I. Haddeland ${ }^{15}$, N. Khabarov ${ }^{16}$, M. Lomas $^{17}$, Y. Masaki ${ }^{18}$, K. Nishina ${ }^{18}$, K. Neumann ${ }^{19,20}$, T. Oki $^{21}$, R. Pavlick ${ }^{22}$, A. C. Ruane ${ }^{23}$, E. Schmid ${ }^{24}$, C. Schmitz ${ }^{1}$, T. Stacke ${ }^{25}$, E. Stehfest ${ }^{20}$, Q. Tang $^{26}$, D. Wisser ${ }^{27}$, V. Huber ${ }^{1}$, F. Piontek ${ }^{1}$, L. Warszawski ${ }^{1}$, J. Schewe ${ }^{1}$, H. Lotze-Campen ${ }^{1}$, and H. J. Schellnhuber ${ }^{1,28}$

${ }^{1}$ Potsdam Institute for Climate Impact Research, Potsdam, Germany

${ }^{2}$ University of Chicago, Chicago, Illinois, USA

${ }^{3}$ ANL Computation Institute, Chicago, Illinois, USA

${ }^{4}$ Karlsruhe Institute of Technology, Karlsruhe, Germany

${ }^{5}$ Utrecht University, Utrecht, the Netherlands

${ }^{6}$ IPSL - LSCE, Gif sur Yvette, France

${ }^{7}$ Centre for Ecology \& Hydrology, Wallingford, UK

${ }^{8}$ Tyndall Centre, School of Environmental Sciences, University of East Anglia, Norwich, UK

Uncertainty in crop production and its role in mitigation

planning

K. Frieler et al.

\section{Title Page}

\section{Abstract}

Introduction

Conclusions

References

Tables

Figures

14

4

Back

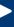

Close

Full Screen / Esc

Printer-friendly Version

Interactive Discussion 
${ }^{9}$ Institute of Physical Geography, J. W. Goethe University, Frankfurt, Germany

${ }^{10}$ Met Office Hadley Centre, Exeter, UK

${ }^{11}$ Civil Engineering Department, The City College of New York, New York, USA

${ }^{12}$ Swiss Federal Institute of Aquatic Science and Technology, Dübendorf, Switzerland

${ }^{13}$ Department of Geography, University of Cambridge, Cambridge, UK

${ }^{14}$ School of Geography, University of Nottingham, Nottingham, UK

${ }^{15}$ Norwegian Water Resources and Energy Directorate, Oslo, Norway

${ }^{16}$ International Institute for Applied System Analysis, Laxenburg, Austria

${ }^{17}$ Centre for Terrestrial Carbon Dynamics, University of Sheffield, Sheffield, UK

${ }^{18}$ Center for Global Environmental Research, National Institute for Environmental Studies,

Tsukuba, Japan

${ }^{19}$ Wageningen University, Laboratory of Geo-information Science and Remote Sensing, Wageningen, the Netherlands

${ }^{20} \mathrm{PBL}$ Netherlands Environmental Assessment Agency, the Hague, the Netherlands

${ }^{21}$ The University of Tokyo, Tokyo, Japan

${ }^{22}$ Max Planck Institute for Biogeochemistry, Jena, Germany

${ }^{23}$ NASA GISS, New York, New York, USA

${ }^{24}$ Institute for Sustainable Economic Development, Vienna, Austria

${ }^{25}$ Max Planck Institute for Meteorology, Hamburg, Germany

${ }^{26}$ Institute of Geographic Sciences and Natural Resources Research, Chinese Academy of Sciences, Beijing, China

${ }^{27}$ Center for Development Research, University of Bonn, Bonn, Germany

${ }^{28}$ Santa Fe Institute, Santa Fe, New Mexico, USA

Received: 28 July 2014 - Accepted: 20 August 2014 - Published: 26 September 2014

Correspondence to: K. Frieler (katja.frieler@pik-potsdam.de)

Published by Copernicus Publications on behalf of the European Geosciences Union.
ESDD

$5,1075-1099,2014$

Uncertainty in crop production and its role in mitigation planning

K. Frieler et al.

\section{Title Page}

Abstract

Introduction

Conclusions

References

Tables

Figures

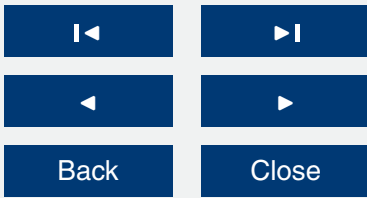

Full Screen / Esc

Printer-friendly Version

Interactive Discussion 


\section{Abstract}

In order to achieve climate change mitigation, long-term decisions are required that must be reconciled with other societal goals that draw on the same resources. For example, ensuring food security for a growing population may require an expansion of 5 crop land, thereby reducing natural carbon sinks or the area available for bio-energy production. Here, we show that current impact-model uncertainties pose an important challenge to long-term mitigation planning and propose a new risk-assessment and decision framework that accounts for competing interests.

Based on cross-sectorally consistent simulations generated within the Inter-Sectoral 10 Impact Model Intercomparison Project (ISI-MIP) we discuss potential gains and limitations of additional irrigation and trade-offs of the expansion of agricultural land as two possible response measures to climate change and growing food demand. We describe an illustrative example in which the combination of both measures may close the supply demand gap while leading to a loss of approximately half of all natural carbon 15 sinks.

We highlight current limitations of available simulations and additional steps required for a comprehensive risk assessment.

\section{Introduction}

Climate change and rising food demand motivate competing responses (Falloon and Betts, 2010; Warren, 2011) resulting in, for example, competition for land between food and bio-energy production (Godfray et al., 2010a; Searchinger et al., 2008; Tilman et al., 2009). Mitigation, in particular, requires long-term planning, which is inevitably done under considerable uncertainty of e.g. future land required for food production.

Models already exist that couple surface hydrology, ecosystem dynamics, crop production (Bondeau et al., 2007; Rost et al., 2008) and agro-economic choices (Havlik et al., 2011; Lotze-Campen et al., 2008a; Stehfest et al., 2013) to address, for example,
ESDD

5, 1075-1099, 2014

Uncertainty in crop production and its role in mitigation planning

K. Frieler et al.

\section{Title Page}

Abstract Introduction

Conclusions References

Tables Figures

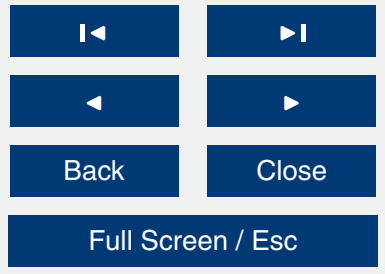

Printer-friendly Version

Interactive Discussion 
carbon-cycle implications of LU changes and irrigation constraints. However, modeling such complicated systems requires a series of assumptions, in particular with respect to process representation and parameter values.

In addition to individual coupled analyses there is a large number of detailed sector5 specific studies covering a wide range of process representations and parameter settings not represented by single, integrative studies (Haddeland et al., 2011; Sitch et al., 2008). A comprehensive assessment as requested by the Intergovernmental Panel on Climate Change (IPCC) must cover the full uncertainty range spanned by these models by quantifying the inter-impact-model spread.

10 Owing to its cross-sectoral design (Warszawski et al., 2013a) the recently launched Inter-Sectoral Impact Model Intercomparison Project (ISI-MIP, http://www.isi-mip.org) provides an opportunity to bring this multi-impact-model dimension to the available integrative analyses of climate change impacts and response options, and allows for a cross-sectoral quantification of uncertainties cascading through the model chain.

An associated risk-assessment framework may be described by two probability density functions (pdfs, see Fig. 1): the red pdf (f) in the upper panel of Fig. 1 describes our knowledge of the required food-production area given certain management decisions (i.e. fertilizer use, irrigation fractions and selection of crop varieties) and a prescribed global-warming level. The width of the distribution is determined by uncertainties in food demand, regional climate change, and crop-model projections describing the effect of climate change and $\mathrm{CO}_{2}$ fertilization on crop yields. Intensification of production, for example by increasing irrigation or fertilizer use, shifts the pdf to the left, since less land would be required to meet demand.

The blue pdf (c) illustrates our knowledge of the area of land required to be maintained as natural carbon sinks or used for bio-energy production in order to limit global warming, for example to $2^{\circ} \mathrm{C}$. We assume that other factors, such as the degree of decarbonisation of the industry, remain fixed. In this case the width of the distribution depends e.g. on uncertainties regarding climate sensitivity and the capacity of the natural carbon sinks as projected by biogeochemical models. Assuming higher energy
ESDD

5, 1075-1099, 2014

Uncertainty in crop production and its role in mitigation planning

K. Frieler et al.

Title Page

Abstract

Conclusions

Tables

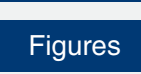

14

4

Back Introduction

References

Figures

$>$ I

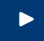

Close

Printer-friendly Version

Interactive Discussion 
efficiency shifts the distribution right as less $\mathrm{CO}_{2}$ has to be extracted from the atmosphere.

Mitigation strategies must compare the area of land required for food production $(F)$ with the associated reduction of the area available for retention of natural carbon sinks 5 and stocks or bio-energy production $(N)$, such that $N=T-F$, where $T=$ total available area. Assuming food demand will always be met, even at the expense of climate protection, the probability of climate protection failure (exceedance of a given global-warming target) is given by

$$
P=\int_{0}^{\infty} \int_{T-F}^{\infty} c(N) d N f(F) d F
$$

10 where the inner integral describes the probability of climate protection failure for a fixed agricultural area $F$ (blue area in Fig. 1). $P$ cannot be determined without knowledge of the uncertainty associated with the required food-production area.

To date, the required pdfs have not yet been quantified except for a first attempt to quantify f based on multiple crop and economic models (Nelson et al., 2013). In this case the economic models evaluate different intensification options or the expansion of agricultural land to translate crop yields and demand into land-use patterns. Here we restrict our analysis to purely biophysical questions and do not provide a full quantification of the different pdfs. We use simulations from 7 Global Gridded Crop Models (GGCMs; Rosenzweig et al., 2013b), 11 global hydrological models (Schewe et al., 2013), and 7 terrestrial bio-geochemical models (Friend et al., 2013; Warszawski et al., 2013b) generated within ISI-MIP to address the following questions in the context of the described risk-assessment framework: (1) how large is the expected future supply-demand gap under climate change and $\mathrm{CO}_{2}$ fertilization assuming present-day land-use (LU) patterns and fixed management (see Table S1 in the Supplement)?;

25 (2) how much can be gained from additional water-availability-limited irrigation without land expansion?; and (3) what are the costs in terms of natural carbon sinks and stocks of an illustrative LU pattern that provides a chance to meet future demand?
ESDD

5, 1075-1099, 2014

Uncertainty in crop production and its role in mitigation planning

K. Frieler et al.

Title Page

Abstract Introduction

Conclusions References

Tables Figures

14

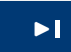

4

Back

Full Screen / Esc

Printer-friendly Version

Interactive Discussion 
Not all of the crop models provide yield projections starting at present day levels (Rosenzweig et al., 2013a). In particular, EPIC provides potential yields assuming high fertilizer input, and LPJ-GUESS does not account for nutrient constraints. Therefore, we only compare relative changes in global production to relative changes in demand. 5 Whilst the assumption that the effects of climate change are relatively independent from the starting conditions is not necessarily valid, we focus on illustrating how such a comprehensive risk assessment could be conducted.

\section{Data and methods}

\subsection{Input data for impact model simulations}

10 All impact projections used within this study are forced by the same climate input data (Warszawski et al., 2013a). For ISI-MIP daily climate data of five General Circulation Models (GCMs) derived from the CMIP5 archive (Taylor et al., 2012) were bias-corrected to match historical reference levels (Hempel et al., 2013). Here, we only use data from HadGEM2-ES, IPSL-CM5A-LR and MIROC-ESM-CHEM (see Ta-

15 ble $\mathrm{S} 6$ in the Supplement) as these models reach a global mean warming of at least $4^{\circ}$ w.r.t. 1980-2010 levels under the Representative Concentration Pathway RCP8.5 the highest of the four RCPs (Moss et al., 2010). All model runs accounting for changes in $\mathrm{CO}_{2}$ concentrations are based on the relevant $\mathrm{RCP}-\mathrm{CO}_{2}$ input.

\subsection{LU patterns and demand}

20 The illustrative LU patterns applied to answer question three are based on projections of the agro-economic LU model MAgPIE (Lotze-Campen et al., 2008b; Schmitz et al., 2012) generated within the ISI-MIP-AgMIP cooperation and published in Nelson et al. (2013). The model computes land-use patterns necessary to fulfill the future demand (Bodirsky et al., 2014). The associated land use projections are based

\section{ESDD}

5, 1075-1099, 2014

Uncertainty in crop production and its role in mitigation planning

K. Frieler et al.

\section{Title Page}

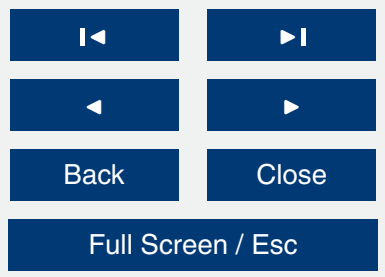

Printer-friendly Version

Interactive Discussion 
on the historical and RCP8.5 simulations by HadGEM2-ES and associated yields provided by LPJmL (Nelson et al., 2013). The pattern is based on fixed $\mathrm{CO}_{2}$-concentration (370 ppm) crop-model simulations. MAgPIE accounts for technological change increasing crop yields (applied growth rates are listed in Table S4 in the Supplement), while 5 our analysis is based on crop-model simulations accounting for increasing levels of atmospheric $\mathrm{CO}_{2}$ concentrations but no technological change.

\subsection{Impact model simulations}

Our considered crop model ensemble represents the majority of GGCMs currently available to the scientific community (run in partnership with the Agricultural Model 10 Intercomparison and Improvement Project (AgMIP; Rosenzweig et al., 2012)). In their complementarity, the models cover a broad range of crop growth mechanisms and assumptions. The quantity projected differs from model to model, ranging from yields constrained by current management deficiencies to potential yields under effectively unconstrained nutrient supply (Table $\mathrm{S} 1$ in the Supplement and Rosenzweig et al., $2013 b)$. The default configuration of most models includes an adjustment of the sowing dates in response to climate change, while total heat units to reach maturity are held constant except for PEGASUS and LPJ-GUESS. Three models include an automatic adjustment of cultivars. The applied hydrological and biomes models and their basic characteristics are listed in Tables S3 and S5 in the Supplement, respectively.

\subsection{Partitioning of the uncertainty budget associated with crop production changes}

To separate the climate model induced uncertainty from the impact model uncertainty the GGCM-specific spread of the relative crop production changes at different levels of global warming is estimated by the standard deviation of the GGCM-specific mean values calculated over all climate model- (and RCP-) specific individual values (e.g. colored dots in Fig. 2) or all water-model-specific individual values in case of
ESDD

5, 1075-1099, 2014

Uncertainty in crop production and its role in mitigation planning

K. Frieler et al.

\section{Title Page}

Abstract Introduction

Conclusions References

Tables Figures

14 4

Back

Full Screen / Esc

Printer-friendly Version

Interactive Discussion 
the production under maximum irrigation. The climate model or water-model-induced spread is estimated as the standard deviation over the individual deviation from these GGCM means.

\section{Results}

\subsection{Adaptive pressure on future food production}

Crop models project a wide range of relative changes in global wheat, maize, rice and soy production at different levels of global warming and associated $\mathrm{CO}_{2}$ concentrations (first column of each global mean warming box in Fig. 2). At $4{ }^{\circ} \mathrm{C}$ the GGCM spread is more than a factor 5 larger than the spread due to the different climate models 10 (estimated as described in Sect. 2.4) (wheat: $13 \%$ vs. $2 \%$, maize: $18 \%$ vs. $2 \%$, rice: $33 \%$ vs. $2 \%$, and soy: $28 \%$ vs. $4 \%$ ). This is partly due to the bias correction of the climate projections, which includes a correction of the historical mean temperature to a common observational data set (Hempel et al., 2013), and may depend on the selection of the three GCMs. However, the results suggest that the inter-crop-model spread will a major component of the uncertainty distribution associated with the area of crop land required to meet future food demand.

Production changes are evaluated in the context of potential demand changes based on population and GDP projections. We consider the "middle of the road" Shared Socioeconomic Pathway (SSP2) (Kriegler et al., 2010) (red lines in Fig. 2). Despite considerable uncertainty, it is evident that even if global production increases based on optimistic assumptions about $\mathrm{CO}_{2}$ fertilization, this effect alone is unlikely to balance demand increases driven by population growth and economic development (assuming that the observed relationship between per capita consumption patterns and incomes holds in the future and ignoring demand-side measures; Foley et al., 2011; Parfitt et al., 2010). In terms of the risk-assessment framework, the projections mean that there is a probability of $100 \%$ that the considered present-day LU and default management
ESDD

$5,1075-1099,2014$

Uncertainty in crop production and its role in mitigation planning

K. Frieler et al.

\section{Title Page}

Abstract Introduction

Conclusions References

Tables Figures

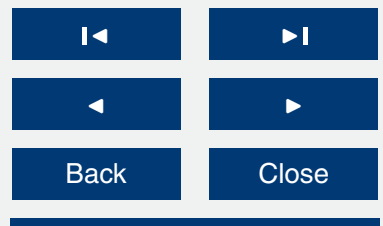

Full Screen / Esc

Printer-friendly Version

Interactive Discussion 
as implemented in the models is not sufficient to meet the estimated food demand in 2050.

All GGCMs show a quasi-linear dependence on global mean temperature across the three different climate models, considered scenarios and range of global mean temper5 ature changes (Figs. S5-S6 in the Supplement). Values range from -3 to $+7 \%{ }^{\circ} \mathrm{C}^{-1}$ for wheat, -8 to $+6 \%{ }^{\circ} \mathrm{C}^{-1}$ for maize, -4 to $+19 \%{ }^{\circ} \mathrm{C}^{-1}$ for rice and -8 to $+12 \%{ }^{\circ} \mathrm{C}^{-1}$ for soy (Table S2 in the Supplement, cf. Rosenzweig et al., 2014 for an update of the IPCCAR4 Table 5.2 (Easterling et al., 2007)). It is not necessarily clear that crop-production changes can be expressed in a path-independent way as a function of global mean 10 temperature change. In particular, $\mathrm{CO}_{2}$ concentrations are expected to modify the relationship with global mean temperature. However, for the $7 \mathrm{GGCMs}$ and the RCP scenarios considered here the path dependence is weak (Figs. S1-S4 in the Supplement). This suggests that the red pdfs shown in Fig. 1 could also be determined for specific global warming (and $\mathrm{CO}_{2}$ ) levels, but relatively independent of the specific pathway.

The disagreement in the sign of the change in crop production in Fig. 2 arises predominantly from differences in the strength of the $\mathrm{CO}_{2}$ fertilization effect. Projections based on fixed $\mathrm{CO}_{2}$ levels show a smaller spread and a general decrease in global production with increasing global warming (Table S2 and Fig. S6 in the Supplement). Given the ongoing debate about the efficiency of $\mathrm{CO}_{2}$ fertilization, in particular under

field conditions (Leakey et al., 2009; Long et al., 2006; Tubiello et al., 2007), and the fact that most models do not account for nutrient constraints of this effect, projections are likely to be optimistic about the growth-promoting effects of increased atmospheric $\mathrm{CO}_{2}$ concentrations.

\subsection{Irrigation potential}

25 Using different means of intensifying crop production on existing crop land, the red uncertainty distributions in Fig. 1 can be shifted to the left. For example, we discuss the potential production increase due to expansion of irrigated areas based on water availability, using only present-day agricultural land. The effect is constrained by
ESDD

5, 1075-1099, 2014

Uncertainty in crop production and its role in mitigation planning

K. Frieler et al.

Title Page

Abstract Introduction Conclusions References Tables Figures

14

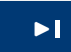

4

Back

Full Screen / Esc

Printer-friendly Version

Interactive Discussion 
(1) biophysical limits of yield response to irrigation, and (2) water availability. For illustrative purposes we assume that irrigation water (plus a minor component of water for industrial and household uses) is limited to $40 \%$ (Gerten et al., 2011) of the annual runoff integrated over the area of one Food Production Unit (FPU; Kummu et al., 5 2010). In addition, we assume a project efficiency of $60 \%$, where $60 \%$ of the irrigation water is ultimately available for the plant. Runoff projections are based on 11 hydrological models participating in ISI-MIP (Table S3 in the Supplement). The available water is distributed according to where it leads to the highest yield increases per applied amount of water, as calculated annually. The approach only accounts for renewable surface and groundwater (for details of the method see Supplement).

While potential expansion of irrigation (or reduction, in the case of insufficient water availability for full irrigation of currently-irrigated areas) could compensate for the climate-induced adaptive pressure projected by some GGCMs (second column of each global mean warming level in Fig. 2), the feasible increase in global production is in15 sufficient to balance the relative increase in demand by the end of the century. For example, the production gap that needs to be overcome through additional technological progress or land-use changes amounts to $60 \%$ (40-70\%) (median, min and max based on the GGCM-specific dots in Fig. 2) at $2{ }^{\circ} \mathrm{C}$ in 2050 for wheat w.r.t. average 1980-2010 production. In the case of rice, which is to a large extent already irrigated 20 (Fig. S3 in the Supplement), the imposed water limitation reduces production in comparison to full irrigation on currently irrigated areas for some of the GGCMs (see Elliott et al., 2013 for a more detailed discussion of limits of irrigation on currently irrigated land).

In terms of Fig. 1, additional irrigation shifts the red uncertainty distributions to the 25 left. However, even with this shift, it remains unlikely that the currently cultivated land will be sufficient to fulfill future food demand.

The spread of projections of global crop production under additional irrigation is dominated by the differences between GGCMs rather than the projections of available water (the partitioning of uncertainty is described in Sect. 2.4). Based on the HadGEM2-ES,
ESDD

5, 1075-1099, 2014

Uncertainty in crop production and its role in mitigation planning

K. Frieler et al.

Title Page

Abstract Introduction Conclusions References Tables Figures

14

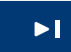

4

Back

Printer-friendly Version

Interactive Discussion 
RCP8.5 climate projections, the GGCM-induced ( 5 models provide the necessary information) spread at $4^{\circ} \mathrm{C}$ is at least a factor of 4 larger than the spread induced by the hydrological models (wheat: wheat: $17 \%$ vs. $4 \%$, maize: $21 \%$ vs. $3 \%$, rice: $36 \%$ vs. $2 \%$, soy: $41 \%$ vs. $3 \%$ ).

5 The production levels shown in Fig. 2 do not reveal whether the increase is mainly biophysically limited by potential yields under full irrigation, or by water availability. Further analysis (Fig. S7 in the Supplement) shows that production under the highly optimistic assumptions regarding water distribution is relatively close to production under unlimited irrigation on present day crop areas with the exception of wheat. In addition, 10 we calculated the distance from rainfed production and production under full irrigation for different project efficiencies (see Fig. S8 in the Supplement), respectively.

\subsection{Effect of LU changes on global crop production}

Intensification options are certainly not exhausted by additional irrigation. For example, other possibilities include improved fertilizer application, switching to higher yielding 5 varieties, or implementing systems of multiple cropping per year. Historically, most of the long-term increase in crop demand was met by a variety of intensification options (Godfray et al., 2010b; Tilman et al., 2011). However, the expansion of arable land may become more important in light of further increasing demand and possibly saturating increases in crop yields (Alston et al., 2009; Lin and Huybers, 2012). A recent study 20 (Ray et al., 2013) suggests that observed increases in yields will not be sufficient to meet future demand.

To illustrate the potential to increase yields via land-use change, we apply a LU pattern generated by the agro-economic LU model MAgPIE for the year 2085 (Sect. 2.2) in combination with the water distribution scheme discussed above (see third column 25 of each global mean warming bin in Fig. 2). There is a very large spread in the relative changes in crop production w.r.t. 1980-2010 reference values, reaching standard deviations of $31 \%$ for wheat, $84 \%$ for maize, $80 \%$ for rice, and $79 \%$ for soy at $4{ }^{\circ} \mathrm{C}$, and in one case even leading to a reduction in production. That may be due to the fact
ESDD

5, 1075-1099, 2014

Uncertainty in crop production and its role in mitigation planning

K. Frieler et al.

Title Page

Abstract Introduction

Conclusions References

Tables Figures

14

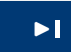

4

Back

Full Screen / Esc

Printer-friendly Version

Interactive Discussion 
that MAgPIE's optimization scheme results in highly concentrated agricultural patterns by 2085 , exaggerating regional features of the GGCM simulations (Figs. S9-S12 in the Supplement). The relative increase in production by some crop models exceeds the projected demand increase. However, in spite of the strong expansion of cultivated 5 land, with particularly high losses in the Amazon rainforest (see Fig. S14 in the Supplement), the lower ends of the samples still do not balance the projected demand increase in 2050 (except for wheat). In terms of Fig. 1 these results indicate a very wide uncertainty distribution associated with the area required for food production. The level of expansion given by the MAgPIE pattern does not seem to be sufficient to fulfill 10 the future demand with high confidence.

\subsection{Effect of LU changes on natural carbon sinks and stocks}

The increase in production by LU changes comes at the cost of natural vegetation. The considered illustrative reduction of the area of natural vegetation reaches $480 \mathrm{Mha}$ in 2085 compare to 1995 levels. To estimate the associated potential loss of carbon sinks, 15 the ecosystem-atmosphere carbon flux is spatially integrated over, (1) the 1995 area of natural vegetation provided by MAgPIE in each year; and (2) the shrinking area of natural vegetation. Biophysical simulations are based on HadGEM2-ES and RCP8.5. For all but one vegetation model (Hybrid) the reduction of the area of natural vegetation (Fig. 3) means a loss of carbon sinks. There is a wide spread in losses, in some 20 cases reaching $50 \%$ compared to the reference period (see Table 1). For the Hybrid model natural vegetation turns into a carbon source over the fixed 1995 area of natural vegetation by mid-century (cf. Friend et al., 2013) (Fig. S15 in the Supplement), which means that a reduction in natural vegetation leads to an increase in the global carbon sink. Our approach does not account for the carbon released from soil after LU

changes (Smith, 2008). While agricultural land can be considered as carbon neutral to first order (cultivated plants are harvested and consumed), the conversion process emits carbon to the atmosphere as soil carbon stocks typically degrade after deforestation (Müller et al., 2007). The direct reduction of the vegetation carbon stock reaches a

\section{ESDD}

$5,1075-1099,2014$

Uncertainty in crop production and its role in mitigation planning

K. Frieler et al.

Title Page

Abstract

Conclusions

Tables

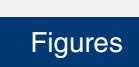

14

4

Back Introduction References Figures

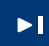
$\triangleright$ Close

Full Screen / Esc

Printer-friendly Version

Interactive Discussion 
multi-model median of about $85 \mathrm{Pg}$ (about 8.5 years of current $\mathrm{CO}_{2}$ emissions) by the end of the century. Results for the experiments with fixed present-day $\mathrm{CO}_{2}$ are shown in Fig. S16 in the Supplement.

\section{Discussion and conclusion}

5 The competition between food security for a growing population and the protection of ecosystems and climate poses a dilemma. This dilemma is fundamentally cross sectoral, and its analysis requires an unprecedented cross-sectoral, multi-impact-modelanalysis of the adaptive pressures on global food production and possible response strategies. To date, a full quantification of the probability distributions necessary to 10 address the issue in a risk-assessment framework has been inhibited by the lack of cross-sectorally consistent multi-impact-model projections. Here, simulations generated within ISI-MIP were applied to achieve the first steps to address the gap.

The spread across different impact models is shown to be a major component of the uncertainty of climate impact projections. In the case of multiple interests and conflict15 ing response measures this uncertainty means a dilemma as ensuring one target with high certainty means putting another one at particularly high risk.

For a full quantification of the probability distributions illustrated in Fig. 1 multiple crop models, simulations and projections of socio-economic development have to be translated into a pdf of the "required food production area" accounting, for example, for changing trade patterns (Nelson et al., 2013). This integration has already started within the AgMIP-ISI-MIP cooperation and will enable the generation of a probability distribution of the required food production area. However, current estimates (Nelson et al., 2013) are based on crop model runs that do not account for the $\mathrm{CO}_{2}$-fertilization effect and only a limited number of models provide explicit LU patterns in addition to the aggregated area.

To estimate the associated risk for climate protection, carbon emissions due to the loss of natural carbon sinks and stocks, particularly including effects of soil degradation,
ESDD

5, 1075-1099, 2014

Uncertainty in crop production and its role in mitigation planning

K. Frieler et al.

\section{Title Page}

Abstract Introduction

Conclusions References

Tables Figures

\section{4}

4

Back

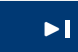

$>$

Close

Full Screen / Esc

Printer-friendly Version

Interactive Discussion 
must be quantified. Therefore, the set of demand-fullfilling LU-patterns has to be provided as input for multi-model biomes simulations. ISI-MIP is designed to facilitate this kind of cross-sectoral integration, which can then be employed to fulfil the urgent demand for a comprehensive assessment of the impacts of climate change, and our 5 options to respond to these impacts and socio-economic developments, along with the corresponding trade-offs.

Our illustration of the uncertainty dilemma is by no means complete. In addition to the irrigation scheme considered here, a more comprehensive consideration of management options for increasing crop yields on a given land area is required. To this 10 end, the representation of management within the crop model simulations needs to be harmonized to quantify the effect of different management assumptions on crop-model projections. These effects of these assumptions should be considered separately to the crop-model spread due to uncertain representation of biophysical processes.

\section{The Supplement related to this article is available online at doi:10.5194/esdd-5-1075-2014-supplement.}

Acknowledgements. We acknowledge the World Climate Research Programme's Working Group on Coupled Modelling, which is responsible for CMIP, and thank the climate modeling groups (listed in Table S6 in the Supplement) for producing and making available their model output. For CMIP the US Department of Energy's Program for Climate Model Diagnosis and Intercomparison provides coordinating support and led development of software infrastructure in partnership with the Global Organization for Earth System Science Portals. This work has been conducted under the framework of ISI-MIP and in cooperation with AgMIP. The ISI-MIP Fast Track project was funded by the German Federal Ministry of Education and Research (BMBF) with project funding reference number 01LS1201A. Responsibility for the content of 25 this publication lies with the author. The research leading to these results has received funding from the European Community's Seventh Framework Programm (FP7 2007-2013) under grant agreement no. 238366 and was supported by the Federal Ministry for the Environment, Nature Conservation and Nuclear Safety (11 II 093 Global A SIDS and LDCs). Pete Falloon was 1088
ESDD

5, 1075-1099, 2014

Uncertainty in crop production and its role in mitigation planning

K. Frieler et al.

\section{Title Page}

Abstract Introduction

Conclusions References

Tables Figures

14

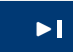

4

Back

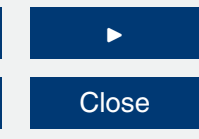

Full Screen / Esc

Printer-friendly Version

Interactive Discussion 
supported by the Joint DECC/Defra Met Office Hadley Centre Climate Programme (GA01101). The research leading to these results has received funding from the European Union's Seventh Framework Programme [FP7/2007-2013] under grant agreement no. 266992. Y. Masaki and K. Nishina were supported by the Environment Research and Technology Development Fund 5 (S-10) of the Ministry of the Environment, Japan.

\section{References}

Alston, J. M., Beddow, J. M., and Pardey, P. G.: Agricultural research, productivity, and food prices in the long run, Science, 325, 1209-1210, doi:10.1126/science.1170451, 2009.

Bodirsky, B. L., Rolinski, S., Biewald, A., Weindl, I., Popp, A., and Lotze-Campen, H.: Global food demand scenarios for the 21st century, Food Security, under review, 2014.

Bondeau, A., Smith, P. C., Zaehle, S., Schaphoff, S., Lucht, W., Cramer, W., Gerten, D., LotzeCampen, H., Müller, C., Reichstein, M., and Smith, B.: Modelling the role of agriculture for the 20th century global terrestrial carbon balance, Global Chang. Biol., 13, 679-706, doi:10.1111/j.1365-2486.2006.01305.x, 2007.

15 Easterling, W. E., Aggarwal, P. K., Batima, P., Brander, K. M., Erda, L., Howden, S. M., Kirilenko, A., Morton, J., Soussana, J.-F., Schmidhuber, J., and Tubiello, F. N.: Climate change 2007: Impacts, Adaptation and Vulnerability, Chaper 5: Food, Fibre and Forest Products, in: Contribution of Working Group II to the Fourth Assessment Report of the Intergovernmental Panel on Climate Change, Cambridge, UK, 2007.

Falloon, P. D. and Betts, R. A.: Climate impacts on European agriculture and water management

Foley, J. A., Ramankutty, N., Brauman, K. A., Cassidy, E. S., Gerber, J. S., Johnston, in the context of adaptation and mitigation - the importance of an integrated approach, Sci. Total Environ., 408, 5667-5687, 2010.

Elliott, J., Deryng, D., M üller, C., Frieler, K., Konzmann, M., Gerten, D., Glotter, M., Flörke, M., Wada, Y., Eisner, S., Folberth, C., Foster, I., Gosling, S. N., Haddeland, I., Khabarov, N., Ludwig, F., Masaki, Y., Olin, S., Rosenzweig, C., Ruane, A., Satoh, Y., Schmid, E., Stacke, T., Tang, Q., and Wisser, D.: Constraints and potentials of future irrigation water availability on agricultural production under climate change, P. Natl. Acad. Sci. USA, 111, 3239-3244, doi:10.1073/pnas.1222474110, 2013.

M., Mueller, N. D., O'Connell, C., Ray, D. K., West, P. C., Balzer, C., Bennett, E. M.,
ESDD

$5,1075-1099,2014$

Uncertainty in crop production and its role in mitigation planning

K. Frieler et al.

\section{Title Page}

Abstract Introduction

Conclusions References

Tables Figures

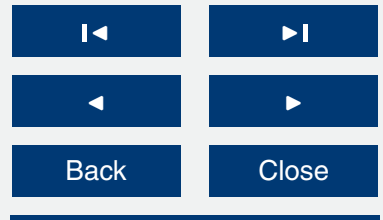

Full Screen / Esc

Printer-friendly Version

Interactive Discussion 
Carpenter, S. R., Hill, J., Monfreda, C., Polasky, S., Rockström, J., Sheehan, J., Siebert, S., Tilman, D., and Zaks, D. P. M.: Solutions for a cultivated planet, Nature, 478, 337-342, doi:10.1038/nature10452, 2011.

Friend, A. D., Richard, B., Patricia, C., Philippe, C., Douglas, B. C., Rutger, D., Pete, F., Akihiko, $5 \quad$ I., Ron, K., Rozenn, M., Axel, K., Mark, R., Wolfgang, L., Nishina, K., Sebastian, O., Ryan, P., Peylin, P., Tim, T. R., Sibyll, S., Vuichard, N., Lila, W., Wiltshire, A., and lan, W.: Carbon residence time dominates uncertainty in terrestrial vegetation responses to future climate and atmospheric $\mathrm{CO}_{2}$, P. Natl. Acad. Sci. USA, 111, 3280-3285, doi:10.1073/pnas.1222477110, 2013.

10 Gerten, D., Heinke, J., Hoff, H., Biemans, H., Fader, M., and Waha, K.: Global Water Availability and Requirements for Future Food Production, J. Hydrometeorol., 12, 885-899, 2011.

Godfray, H. C. J., Beddington, J. R., Crute, I. R., Haddad, L., Lawrence, D., Muir, J. F., Pretty, J., Robinson, S., Thomas, S. M., and Toulmin, C.: Food security: the challenge of feeding 9 billion people, Science, 327, 812-818, doi:10.1126/science.1185383, 2010a.

Godfray, H. C. J., Crute, I. R., Haddad, L., Lawrence, D., Muir, J. F., Nisbett, N., Pretty, J., Robinson, S., Toulmin, C., and Whiteley, R.: The future of the global food system, Philos. T. Roy. Soc. Lond. B, 365, 2769-2777, doi:10.1098/rstb.2010.0180, 2010b.

Haddeland, I., Clark, D. B., Franssen, W., Ludwig, F., Voß, F., Arnell, N. W., Bertrand, N., Best, M., Folwell, S., Gerten, D., Gomes, S., Gosling, S. N., Hagemann, S., Hanasaki, N., Harding, R., Heinke, J., Kabat, P., Koirala, S., Oki, T., Polcher, J., Stacke, T., Viterbo, P., Weedon, G. P., and Yeh, P.: Multimodel Estimate of the Global Terrestrial Water Balance: Setup and First Results, J. Hydrometeorol., 12, 869-884, doi:10.1175/2011JHM1324.1, 2011.

Havlik, P., Schneider, U. A., Schmid, E., Böttcher, H., Fritz, S., Skalskỳ, R., Aoki, K., De Cara, S., Kindermann, G., Kraxner, F., Leduc, S., McCallum, I., Mosnier, A., Sauer, T., and Obersteiner, M.: Global land-use implications of first and second generation biofuel targets, Energy Policy, 39, 5690-5702, 2011.

Hempel, S., Frieler, K., Warszawski, L., Schewe, J., and Piontek, F.: A trend-preserving bias correction - the ISI-MIP approach, Earth Syst. Dynam., 4, 219-236, doi:10.5194/esd-4-2192013, 2013.

30 Kriegler, E., O’Neill, B. C., Hallegatte, S., Kram, T., Lempert, R. J., Moss, R. H., and Wilbanks, T.: The need for and use of socio-economic scenarios for climate change analysis: a new approach based on shared socio-economic pathways, Global Environ. Change, 22, 807822, 2012.
ESDD

5, 1075-1099, 2014

Uncertainty in crop production and its role in mitigation planning

K. Frieler et al.

Title Page

Abstract Introduction

Conclusions References

Tables Figures

14

4

Back

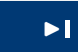

$>$

Close

Printer-friendly Version

Interactive Discussion 
Kummu, M., Ward, P., de Moel, H., and Varis, O.: Is physical water scarcity a new phenomenon? global assessment of water shortage over the last two millennia, Environ. Res. Lett., 5, 034006, doi:10.1088/1748-9326/5/3/034006, 2010.

Leakey, A. D. B., Ainsworth, E. A., Bernacchi, C. J., Rogers, A., Long, S. P., and Ort, D. R.: 5 Elevated $\mathrm{CO}_{2}$ effects on plant carbon, nitrogen, and water relations: six important lessons from FACE, J. Exp. Bot., 60, 2859-2876, 2009.

Lin, M. and Huybers, P.: Reckoning wheat yield trends, Environ. Res. Lett., 7, 024016, doi:10.1088/1748-9326/7/2/024016, 2012.

Long, S. P., Ainsworth, E. A., Leakey, A. D. B., Nösberger, J., and Ort, D. R.: Food for thought: lower-than-expected crop yield stimulation with rising $\mathrm{CO}_{2}$ concentrations, Science, 312, 1918-21, doi:10.1126/science.1114722, 2006.

Lotze-Campen, H., Müller, C., Bondeau, A., Rost, S., Popp, A., and Lucht, W.: Global food demand, productivity growth, and the scarcity of land and water resources: a spatially explicit mathematical programming approach, Agric. Econ., 39, 325-338, doi:10.1111/j.15740862.2008.00336.x, 2008a.

Lotze-Campen, H., Müller, C., Bondeau, A., Rost, S., Popp, A., and Lucht, W.: Global food demand, productivity growth, and the scarcity of land and water resources: a spatially explicit mathematical programming approach, Agric. Econ., 39, 325-338, 2008b.

Moss, R. H., Edmonds, J. A., Hibbard, K. A., Manning, M. R., Rose, S. K., van Vuuren, D. P., Carter, T. R., Emori, S., Kainuma, M., Kram, T., Meehl, G. A., Mitchell, J. F. B., Nakicenovic, N., Riahi, K., Smith, S. J., Stouffer, R. J., Thomson, A. M., Weyant, J. P., and Wilbanks, T. J.: The next generation of scenarios for climate change research and assessment, Nature, 463, 747-756, 2010.

Müller, C., Eickhout, B., Zaehle, S., Bondeau, A., Cramer, W., and Lucht, W.: Effects of changes in $\mathrm{CO}_{2}$, climate, and land use on the carbon balance of the land biosphere during the 21st century, J. Geophys. Res., 112, G02032, doi:10.1029/2006JG000388, 2007.

Nelson, G. C., Ahammad, H., Deryng, D., Elliott, J., Fujimori, S., Havlik, P., Heyhoe, E., Page, K., von Lampe, M., Lotze-Campen, H., Daniel Mason, D., van Meijl, H., van der Mensbrugghe, D., Müller, C., Robertson, R., Sands, R. D., Schmid, E., Schmitz, C., Tabeau, A., Valin, H., and shocks, P. Natl. Acad. Sci. USA, 111, 3274-3279, doi:10.1073/pnas.1222465110, 2013.

ESDD

5, 1075-1099, 2014

\section{Uncertainty in crop production and its role in mitigation planning}

K. Frieler et al.

\section{Title Page}

Abstract Introduction

Conclusions References

Tables Figures

14

4

Back

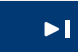

$>$

Close

Full Screen / Esc

Printer-friendly Version

Interactive Discussion 
Parfitt, J., Barthel, M., and Macnaughton, S.: Food waste within food supply chains: quantification and potential for change to 2050, Philos. T. Roy. Soc. Lond. B, 365, 3065-3081, doi:10.1098/rstb.2010.0126, 2010.

Ray, D. K., Mueller, N. D., West, P. C., and Foley, J. A.: Yield Trends Are Insufficient to Double Global Crop Production by 2050, edited by: Hart, J. P., PLoS One, 8, e66428, doi:10.1371/journal.pone.0066428, 2013.

Rosenzweig, C., Jones, J. W., Hatfield, J. L., Ruane, A. C., Boote, K. J., Thorburn, P., Antle, J. M., Nelson, G. C., Porter, C., Janssen, S., Asseng, S., Basso, B., Ewert, F., Wallach, D., Baigorria, G., and Winter, J. M.: The Agricultural Model Intercomparison and Improvement Project (AgMIP): Protocols and pilot studies, Agr. Forest Meteorol., 170, 166-182, doi:10.1016/j.agrformet.2012.09.011, 2012.

Rosenzweig, C., Elliott, J., Deryng, D., Ruane, A. C., Müller, C., Arneth, A., Boote, K. J., Folberth, C., Glotter, M., Khabarov, N., Neumann, K., Piontek, F., Pugh, T. A. M., Schmid, E., Stehfest, E., Yang, H., and Jones, J. W.: Assessing agricultural risks of climate change in the 21st century in a global gridded crop model intercomparison, P. Natl. Acad. Sci. USA, 14, 1-6, doi:10.1073/pnas.1222463110, 2013a.

Rosenzweig, C., Elliott, J., Deryng, D., Ruane, A. C., Müller, C., Arneth, A., Boote, K. J., Folberth, C., Glotter, M., Khabarov, N., Neumann, K., Piontek, F., Pugh, T. A. M., Schmid, E., Stehfest, E., Yang, H., and Jones, J. W.: Assessing agricultural risks of climate change in the 21 st century in a global gridded crop model intercomparison, P. Natl. Acad. Sci. USA, 111, 3268-3273, doi:10.1073/pnas.1222463110, in press, 2013b.

Rost, S., Gerten, D., Bondeau, A., Lucht, W., Rohwer, J., and Schaphoff, S.: Agricultural green and blue water consumption and its influence on the global water system, Water Resour. Res., 44, 1-17, doi:10.1029/2007WR006331, 2008.

Schewe, J., Heinke, J., Gerten, D., Haddeland, I., Arnell, N. W., Clark, D. B., Dankers, R., Eisner, S., Fekete, B. M., Colón-González, F. J., Gosling, S. N., H., K., Liu, X., Masaki, Y., Portmann, F. T., Satoh, Y., Stacke, T., Tang, Q., Wada, Y., Wisser, D., Albrecht, T., Frieler, K., Piontek, F., Warszawski, L., and Kabat, P.: Multi-model assessment of water scarcity under climate change, P. Natl. Acad. Sci. USA, 111, 3245-2350, doi:10.1073/pnas.1222460110, 2013.

so Schmitz, C., Biewald, A., Lotze-Campen, H., Popp, A., Dietrich, J. P., Bodirsky, B., Krause, M., and Weindl, I.: Trading more food: Implications for land use, greenhouse gas emissions, and the food system, Global Environ. Change, 22, 189-209, doi:10.1016/j.gloenvcha.2011.09.013, 2012.
ESDD

5, 1075-1099, 2014

\section{Uncertainty in crop production and its role in mitigation planning}

K. Frieler et al.

\section{Title Page}

Abstract Introduction

Conclusions References

Tables Figures

14

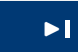

4

Back

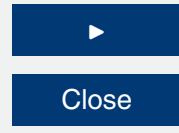

Full Screen / Esc

Printer-friendly Version

Interactive Discussion 
Searchinger, T., Heimlich, R., Houghton, R. A., Dong, F., Elobeid, A., Fabiosa, J., Tokgoz, S., Hayes, D. and Yu, T.-H.: Use of U.S. croplands for biofuels increases greenhouse gases through emissions from land-use change, Science, 319, 1238-1240, doi:10.1126/science.1151861, 2008.

5 Sitch, S., Huntingford, C., Gedney, N., Levy, P. E., Lomas, M., Piao, S. L., Betts, R., Ciais, P., Cox, P., Friedlingstein, P., Jones, C. D., Prentice, I. C., and Woodward, F. I.: Evaluation of the terrestrial carbon cycle, future plant geography and climate-carbon cycle feedbacks using five Dynamic Global Vegetation Models (DGVMs), Global Change Biol., 14, 20152039, doi:10.1111/j.1365-2486.2008.01626.x, 2008.

10 Smith, P.: Land use change and soil organic carbon dynamics, Nutr. Cycl. Agroecosyst., 812, 169-178, 2008.

Stehfest, E., Van Den Berg, M., Woltjer, G., Msangi, S., and Westhoek, H.: Options to reduce the environmental effects of livestock production - Comparison of two economic models, Agric. Syst., 114, 38-53, doi:10.1016/j.agsy.2012.07.002, 2013.

15 Taylor, K. E., Stouffer, R. J., and Meehl, G. A.: An Overview of CMIP5 and the Experiment Design, B. Am. Meteorol. Soc., 93, 485-498, doi:10.1175/BAMS-D-11-00094.1, 2012.

Tilman, D., Socolow, R., Foley, J. A., Hill, J., Larson, E., Lynd, L., Pacala, S., Reilly, J., Searchinger, T., Somerville, C., and Williams, R.: Beneficial Biofuels - The Food, Energy, and Environment Trilemma, Science, 325, 270-271, 2009.

20 Tilman, D., Balzer, C., Hill, J., and Befort, B. L.: Global food demand and the sustainable intensification of agriculture, P. Natl. Acad. Sci. USA, 108, 20260-20264, doi:10.1073/pnas.1116437108, 2011.

Tubiello, F. N., Amthor, J. S., Boote, K. J., Donatelli, M., Easterling, W., Fischer, G., Gifford, R. M., Howden, M., Reilly, J., and Rosenzweig, C.: Crop response to elevated $\mathrm{CO}_{2}$ and world food supply, Eur. J. Agron., 26, 215-223, doi:10.1016/j.eja.2006.10.002, 2007.

Warren, R.: The role of interactions in a world implementing adaptation and mitigation solutions to climate change, Philos. Trans. A. Math. Phys. Eng. Sci., 369, 217-241, doi:10.1098/rsta.2010.0271, 2011.

Warszawski, L., Frieler, K., Huber, V., Piontek, F., Serdeczny, O., and Schewe, J.: The Intersec30 toral Impact Model Intercomparison Project (ISI-MIP): Project framework description, P. Natl. Acad. Sci. USA, 111, 3228-3232, doi:10.1073/pnas.1312330110, 2013a.

Warszawski, L., Friend, A., Ostberg, S., Frieler, K., Lucht, W., Schaphoff, S., Beerling, D., Cadule, P., Ciais, P., Clark, D. B., Kahana, R., Ito, A., Keribin, R., Kleidon, A., Lomas, M., Nishina,
ESDD

5, 1075-1099, 2014

Uncertainty in crop production and its role in mitigation planning

K. Frieler et al.

Title Page

Abstract

Introduction

Conclusions References

Tables

Figures

14

4

Back

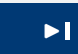

I

$>$

Close

Full Screen / Esc

Printer-friendly Version

Interactive Discussion 
K., Pavlick, R., Rademacher, T. T., Piontek, F., Schewe, J., Serdeczny, O., Buechner, M., and Schellnhuber, H. J.: A multi-model analysis of risk of ecosystem shift under climate change, Environ. Res. Lett., 8, 044018, doi:10.1088/1748-9326/8/4/044018, 2013b.

\section{ESDD}

$5,1075-1099,2014$

Uncertainty in crop production and its role in mitigation planning

K. Frieler et al.

\section{Title Page}

Abstract

Introduction

Conclusions

References

Tables

Figures

14

Back

Full Screen / Esc

Printer-friendly Version

Interactive Discussion 


\section{ESDD}

5, 1075-1099, 2014

Uncertainty in crop production and its role in mitigation planning

Table 1. Maximal loss of carbon sinks and the vegetation carbon stock as estimated for the illustrative LU change scenario (based on colored lines in panel a and b of Fig. 3). The maximum of the transient changes (column 2 and 4 ) is compared to mean values of the C-fluxes and the C-stock averaged over the reference period 1980-2010 (column 3 and 5).

\begin{tabular}{lcccc}
\hline Model & $\begin{array}{c}\text { Max } \Delta \mathrm{C} \text { sink } \\
{\left[\mathrm{Pg} \mathrm{yr}^{-1}\right]}\end{array}$ & $\begin{array}{c}\text { Ref } \\
{\left[\mathrm{Pg} \mathrm{yr}^{-1}\right]}\end{array}$ & $\begin{array}{c}\text { Max } \Delta \text { Cveg } \\
{[\mathrm{Pg}]}\end{array}$ & $\begin{array}{c}\text { Ref } \\
{[\mathrm{Pg}]}\end{array}$ \\
\hline LPJmL & 0.5 & -1.4 & 86 & 201 \\
JULES & 0.1 & -0.6 & 67 & 148 \\
JeDI & 0.4 & -0.7 & 89 & 141 \\
SDGVM & 0.3 & -0.6 & 89 & 161 \\
VISIT & 0.3 & -0.7 & 57 & 126 \\
ORCHIDEE & 0.5 & -0.7 & 121 & 224 \\
Hybrid & 0.0 & -0.6 & 32 & 137
\end{tabular}

Title Page

Abstract

Introduction

Conclusions

References

Tables

Figures

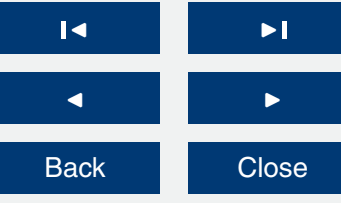

Full Screen / Esc

Printer-friendly Version

Interactive Discussion 


\section{ESDD}

$5,1075-1099,2014$

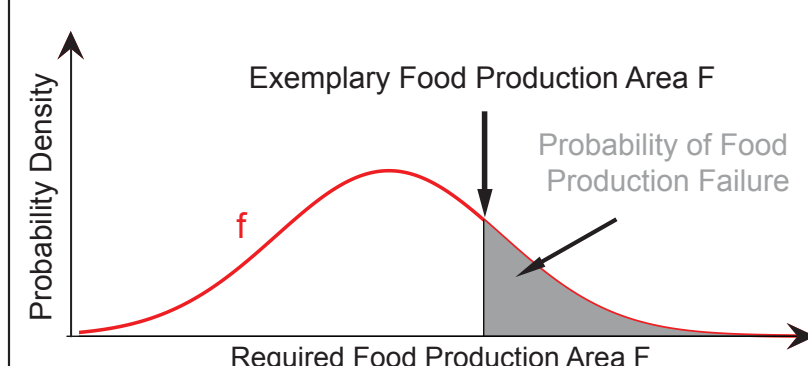

Required Food Production Area F

Required Area of Natural Carbon Sinks or Bioenergy Production N

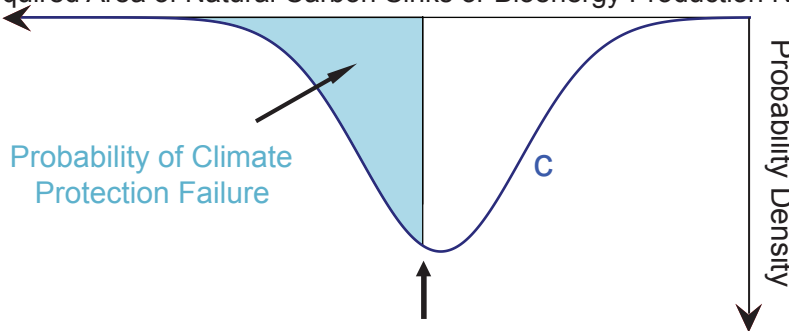

Exemplary Area of Natural Carbon Sinks or Bioenergy Production N = Total Area - F
Figure 1. Land use changes in a risk assessment framework. Red pdf: uncertainty associated with the area of crop land required to fulfill future food demand. Blue pdf: uncertainty associated with the (natural) carbon sinks and stocks required to ensure climate protection.

\section{Uncertainty in crop production and its role in mitigation planning}

K. Frieler et al.

\section{Title Page}

Abstract

Introduction

Conclusions

References

Tables

Figures

14

Back

Full Screen / Esc

Printer-friendly Version

Interactive Discussion 


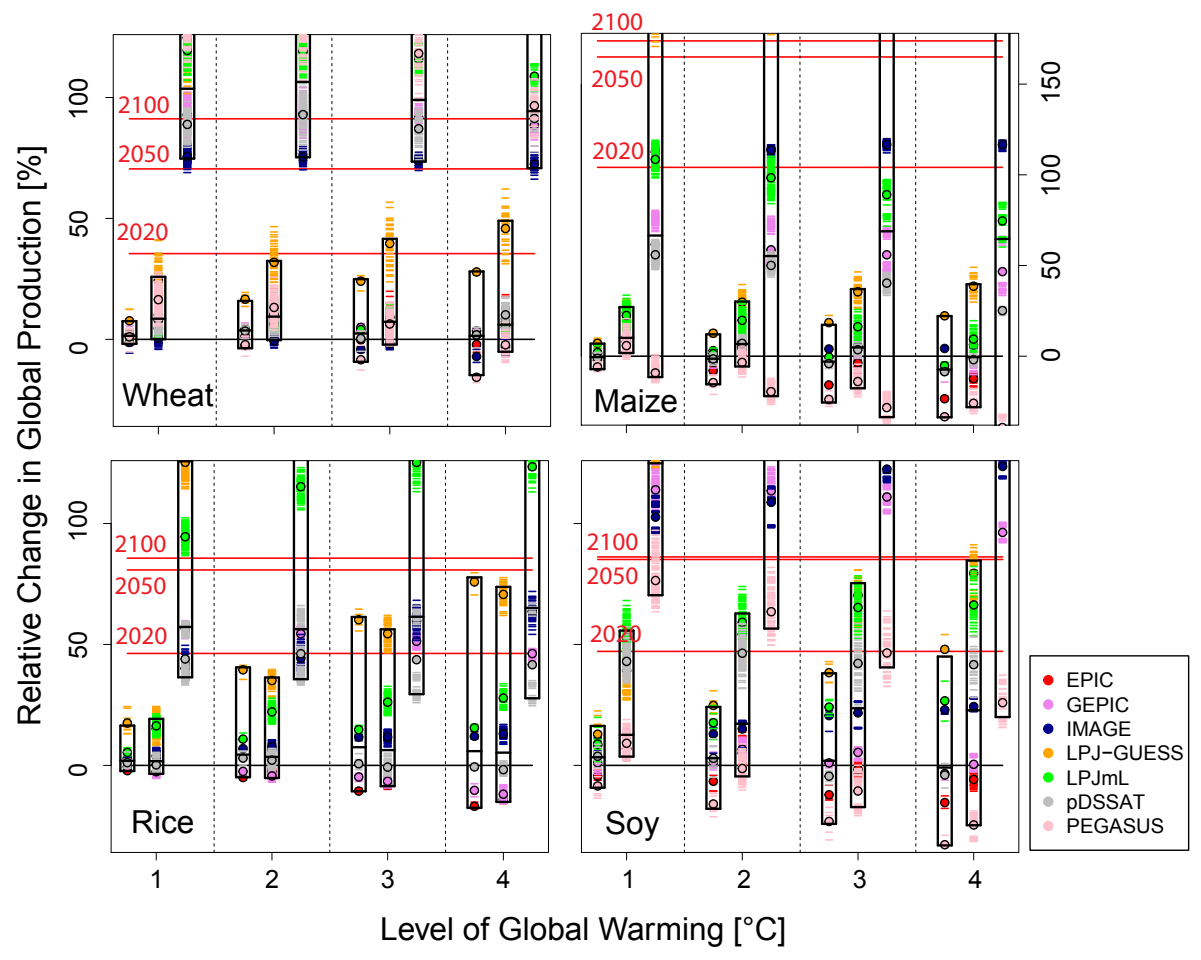

ESDD

5, 1075-1099, 2014

Uncertainty in crop production and its role in mitigation planning

K. Frieler et al.

Title Page

Abstract

Introduction

Conclusions

References

Tables

Figures

14

4

Back

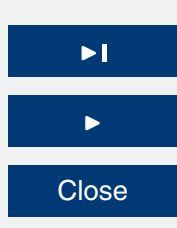

Full Screen / Esc

Printer-friendly Version

Interactive Discussion 
Figure 2. Adaptive pressure on global crop production and effects of irrigation and LU adaptation. Relative changes in crop global production (wheat, maize, rice, soy) at different levels of global warming with respect to the reference data (global production under unlimited irrigation on currently-irrigated land; averaged over the 1980-2010 reference period). Horizontal red lines indicate the relative change in demand projections for the years 2020, 2050, and 2100 due to changes in population and GDP under SSP2. First column of each global mean warming block: change in global production under fixed current LU patterns assuming unlimited irrigation restricted to present-day irrigated land. Second block: relative change (w.r.t. reference data) in global production assuming potential expansion of irrigated land accounting for irrigation water constraints as projected by 11 water models (for details see Supplement). Third column: based on the same water distribution scheme as column 2 but applied to the $2085 \mathrm{LU}$ pattern provided by MAgPIE. EPIC is excluded from the LU experiment as simulations are restricted to present-day agricultural land. Color coding indicates the GGCM. Horizontal bars represent results for individual climate models, RCPs, GGCMs, and hydrological models (for column 2 and 3). Colored dots represent the GGCM-specific means over all GCMs and RCPs (and hydrological models). Black boxes mark the inner $90 \%$ range of all individual model runs. The central black bar of each box represents the median over all individual results.

\section{ESDD}

5, 1075-1099, 2014

Uncertainty in crop production and its role in mitigation planning

K. Frieler et al.

\section{Title Page}

Abstract Introduction

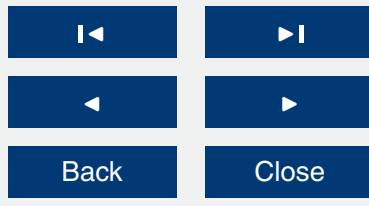

Full Screen / Esc

Printer-friendly Version

Interactive Discussion 


\section{ESDD}

$5,1075-1099,2014$
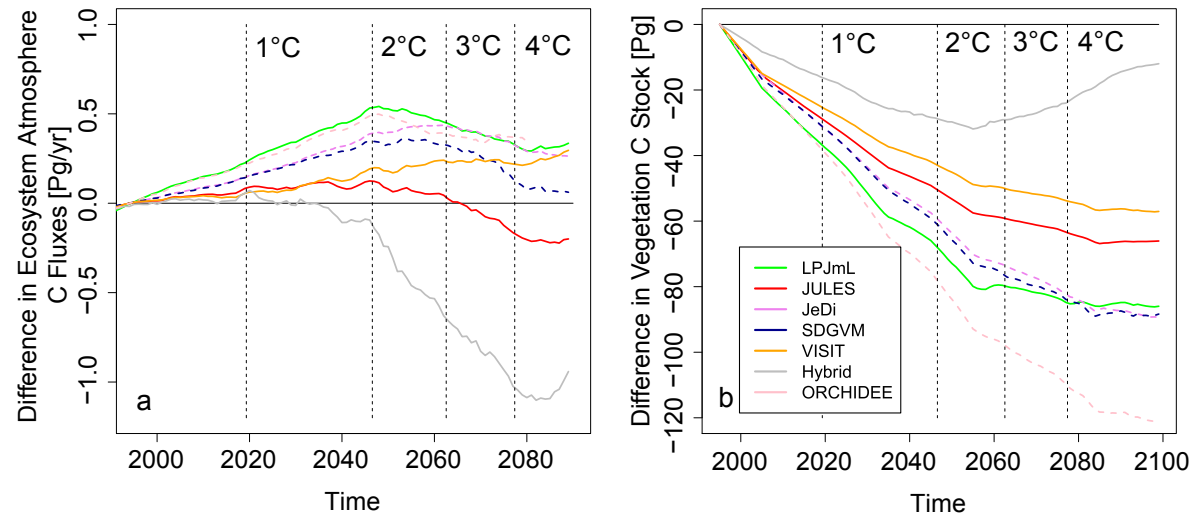

Figure 3. (a) Loss of carbon sinks (ecosystem-atmosphere $C$ flux) due to reduction of natural vegetation and (b) associated changes in the vegetation $C$ stock (Cveg). Colored lines represent 20 year running means of the differences of these variables between the LU change scenario and the reference scenario (fixed 1995 area of natural vegetation). Positive values indicate higher ecosystem-atmosphere $\mathrm{C}$ fluxes and a reduction in Cveg under LU change, respectively. Color coding indicates the different bio-geochemical models. Solid (dashed) lines represent simulations based on dynamic (static) vegetation patterns. Results are based on the historical and RCP8.5 simulations by HadGEM2-ES. Dashed vertical lines: years where the global mean temperature change with respect to $1980-2010$ reaches $1,2,3$, and $4^{\circ} \mathrm{C}$.

\section{Uncertainty in crop production and its role in mitigation planning}

K. Frieler et al.

\section{Title Page}

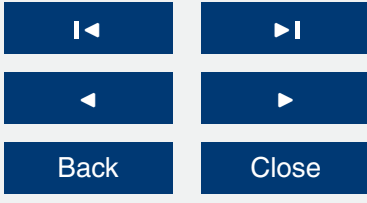

Full Screen / Esc

Printer-friendly Version

Interactive Discussion 